\title{
Knowledge management and intellectual capital of companies in the tourism sector in the Department of Caldas - Colombia
}

\section{Gestión del conocimiento y capital intelectual de las empresas del sector turístico del Departamento de Caldas - Colombia}

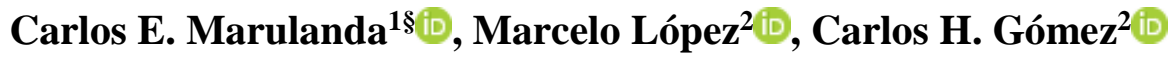 \\ ${ }^{1}$ Universidad Nacional de Colombia, Facultad de Administración, Departamento de Administración, \\ Manizales, Colombia \\ ${ }^{2}$ Universidad de Caldas, Facultad de Ingeniería, Departamento de Sistemas e Informática, Manizales, \\ Colombia \\ §cemarulandae@unal.edu.co,mlopez@ucaldas.edu.co,carlosh@ucaldas.edu.co
}

Recibido: 5 de marzo de 2021 - Aceptado: 27 de julio de 2021

\begin{abstract}
The purpose of this article is to propose a model for evaluating knowledge management (KM) and intellectual capital (IC) to add value to SMEs in the tourism sector in the department of Caldas, Colombia. The article establishes the status of KM and IC in some of its variables and proposes some application alternatives. The study is based on a QA (Quality Assurance) evaluation model and some of the most important characteristics of IC evaluation and is supported by descriptive and correlational analysis. The main findings show the validation of the assessment model and a highly significant correlation of its variables. There is a need to train employees who have direct contact with tourists, both to incorporate good practices and lessons learned and to personalize services and get to know clients in-depth and thus offer service experiences.
\end{abstract}

Keywords: assessment model, competitiveness, Intellectual Capital (IC), Knowledge Management (KM).

\section{Resumen}

El propósito de este artículo es proponer un modelo de evaluación de la gestión del conocimiento (GC) y del capital intelectual (CI) para agregar valor a las pymes del sector turístico del departamento de Caldas, Colombia. El artículo establece el estado de la GC y el CI en algunas de sus variables y propone algunas alternativas de aplicación. El estudio se basa en un modelo de evaluación de la GC y en algunas de las características más importantes de la evaluación del Como citar:

Marulanda CE, López M, Gómez CH. Gestión del conocimiento y capital intelectual de las empresas del sector turístico del Departamento de Caldas - Colombia. INGENIERÍA Y COMPETITIVIDAD. 2022;24(1):e21311058. https://doi.org/10.25100/iyc.v24i1.11058. 
CI y se apoya en un análisis descriptivo y correlacional. Los principales hallazgos muestran la validación del modelo de evaluación y una correlación altamente significativa de sus variables. Es necesario capacitar a los empleados que tienen contacto directo con los turistas, tanto para incorporar buenas prácticas y lecciones aprendidas como para personalizar los servicios y conocer a fondo a los clientes y de esa manera ofrecer experiencias de servicio

Palabras clave: Capital Intelectual (CI), competitividad, Gestión del Conocimiento (GC), modelo de evaluación.

\section{Introduction}

Today's society is characterized by the transition of people management, high flexibility and freedom of business actions, the uncertainty of deregulated markets, and the formation of an interconnected economy in real time, which affects companies and organizations are subject to changes emphasized by competition rivalry, the emergence of new entrepreneurs, products and services with a shorter life cycle, the use and appropriation of information and communications technologies, the development of mobile computing, customer-oriented services, marketing, and innovation ${ }^{(1)}$.

In this context, companies must generate and strengthen their sustainable competitive advantages to respond, adapt and sustain themselves in the face of these changes, and they have done so based on diverse approaches ranging from knowledge management ${ }^{(2)}$, innovation and IT ${ }^{(3)}$ up to continuous improvement ${ }^{(4)}$ and digital transformation (5) among others. Knowledge management has become one of the most important trends for organizations today, by recognizing collaborators as one of their most valuable capitals in which knowledge resides, as a product of the theoretical development of concepts and the application of their related experience. From this point of view, investigations like ${ }^{(6)}$ recognize the potential to make SMEs more competitive and innovative, in order to generate a sustainable yield, and so that their use generates a greater individual and group yield.

However, the changes that the tourism sector is experiencing are the result of a process of many years, however, it is now when they are manifesting and affecting more clearly tourist destinations and tourism companies. This process will compel SMEs (Small and Medium Enterprises) and tourist destinations to work harder if they want both to survive and take advantage of new emerging opportunities. Future challenges will be adventure activities are arranged outdoors and involve participants intentionally pursuing challenges and excitement while interacting with nature. Adventure tourists consider challenging experiences to be one of their primary motivators ${ }^{(7)}$.

In the case of the Caldas department touristic sector, (8) considers that taking advantage of tourism since the declaration of the Cultural Coffee Landscape of the Department of Caldas with large projects to which the sector is focused, but this has difficulties such as the lack of resources, airport connectivity and the curbing of visits to Los Nevados Park in Caldas. In the tourism sector of the Department of Caldas, within a national framework, according to (9), new technologies can contribute to the effective solution of the country's problems. This is why the IT sector is a national priority and is considered the new locomotive for development, which makes it necessary to promote its use as one of the fundamental tools to connect to the globalized world and strengthen its communication channels with potential customers. For this reason, it is necessary to assess the intellectual capital state of SMEs in the touristic sector of Caldas department and thereafter raise and develop strategies from the public and private sector.

\subsection{Knowledge management}

In this sense ${ }^{(10)}$ states that knowledge is the individual's ability to make distinctions within a domain of action, based on an appreciation of 
context or theory, or both. Organizational knowledge is the ability that members of an organization have developed to make distinctions in the process of carrying out their work, in specific contexts. At the same time ${ }^{(11)}$ have given the following definition of knowledge: knowledge is a mixture of flow of framed experiences, values, contextual information that provide a framework for evaluating and incorporating new experiences and information. It originates and it is applied in the minds of practitioners. In organizations, it often manifests itself not only in documents or repositories but also in organizational routines, processes, practices, and standards. Knowledge management $(\mathrm{KM})$ is the process that continuously ensures the development and application of all forms of relevant knowledge in a company, in order to improve its problemsolving capability and thus contribute to the sustainability of its competitive advantages ${ }^{(12)}$ and (13).

Joined to the above ${ }^{(14)}$ states that $\mathrm{KM}$ can be consistent with the theory of resources and capabilities, that is, to build and compete in a capability that could be quite difficult to imitate. In more practical terms, knowledge management is considered fundamentally for the products and process of innovation and improvement, for executive decision making, and the adaptation and renewal of the organization. KM is presented as a discipline whose objective is to develop knowledge in the following phases: acquisition, storage, transformation, distribution, and use, with the aim of achieving competitive advantages (15-17).

The uses and justifications for the use of KM are diverse, ranging from generating changes and sustainable results, optimizing resources, taking advantage of existing knowledge, learning permanently, stimulating creativity and innovation, and even what is proposed by ${ }^{(18-22)}$ whose in their research work show that the combination and exchange of knowledge in an organization is directly correlated with: cost reduction, creativity and product innovation, organizational improvement, increased performance and sales revenue.

Likewise, ${ }^{(23)}$ is particularly noteworthy for the following: KM development should be achieved within the framework of a knowledge society, integrating the main actors, and considering the benefits that the individual should receive, as part of an intricate community in different networks that must participate and interact with each other for the common welfare. This is given the current situations, where the welfare remains in a few, and it is necessary to address the complexity of organizational analysis and its interactions through a way of thinking based on the totality and its properties ${ }^{(24-27)}$.

\subsection{Intellectual capital}

Parallel that, ${ }^{(28)}$ explains that organizations have increasingly realized that knowledge and intellectual assets and intellectual capital (IC) must be managed in a purposeful, systematic and experienced way. To survive progressive managers who have recognized that the viability of the company depends directly on the competitive quality of its knowledge-based intellectuality and the successful application of its assets in its operational activities to add value and to achieve the objectives of the company. KM and IC are fundamentally different, but they complement each other by covering most aspects of a company's activities ${ }^{(29)}$.

What's more, ${ }^{(30)}$ defines IC as the difference between the company's book value and the amount of money someone is willing to pay for it. IC represents intangible assets that often do not appear on the balance sheet and constitute value, often in four categories: Assets that empowers the company in the market: brands, customer loyalty, and business reputation, among others. Assets that represent the property of the intellectual mind: property such as patents, trademarks, and copyrights, among others. Assets that provide the organization with internal strength: corporate 
culture, management, business processes and the strength derived from applying information and communication technologies (IT), among others. Assets derived from the people who work in the organization: such as their knowledge, skills, work-related knowledge, and network capacity, among others.

In addition, ${ }^{(31)}$ explains that IC can be seen as a company's holistic or meta-level ability to coordinate, orchestrate and deploy its knowledge resources to create value in the pursuit of its vision. As well as the economic value of a corporation's intangible assets. It also defines the need to measure it, considering the following postulates: 1) What is measured is managed, 2) Improve the management of intangible resources, 3) Monitor the effects of its actions, 4) Turn the organization's strategy into action, 5) Weigh possible courses of action, and 6) Improve the management of the organization as a whole.

Likewise, ${ }^{(32)}$ and ${ }^{(33)}$ explain that IC is turning into a crucial factor for the long-term performance of a company in a knowledge-based economy, in which the storage and application of knowledge are the basis of development, and it is necessary to generate organizational capacities to create, manage and evaluate learning, as well as to generate value, which is considered the basis for the development of new services and/or products. IC may include: 1) The profit, the income of the product or service, 2) Strategic positionings, such as market share, leadership (innovation), standard setting and brand recognition, 3) Acquisition of third-party innovations, 4) To improve customer loyalty, 5) Cost savings, 6) To improve on productivity, 7) Improving corporate culture and internal relationship, 8) Intellectual property and technology (e.g. organization's patents and trade secrets), 9) Processes and procedures for projects executing, and 10) Relationships with clients, institutions, investors and partners and suppliers.

On the other hand, ${ }^{(34)}$ recounts the subject matter described and found that the development of intellectual capital theory mainly evolved in the late 1980s and early 1990s, a period in which the components of IC were explained and identified, and their respective models were presented. In the first stage, the IC was based on the work of practitioners, with the Skandia Navigator model, as an attempt to show the hidden value of the company rather than its intangible assets; the second stage of CI explored its impact on value creation, financial performance, and visibility through the creation of guidelines and standards; the third stage of CI drives value for creation in products and services; and the fourth stage today concentrates on building strong economic, social and environmental ecosystems of cities and nations from the IC.

In this sense, ${ }^{(35)}$ explains that the IC can create value for the company, increasing its investment and a positive effect on the value of the company measured by the share price; it can improve the financial performance of companies, generate a higher financial performance measured by the profitability of the company, higher revenue growth, return on both assets and patrimony. IC can be knowledge, information, experience, ownership, resources, and organization of the company; it is a collection and synergy of knowledge, experience, invention, innovation, market share and communities that can affect the company, it is a learning process, an optimal exploitation of limited resources and a motivational factor ${ }^{(36)}$.

In this matter, ${ }^{(37)}$ concludes that the IC is a knowledge resource that organizations use to achieve sustainable development and it is clearly linked to the innovation capability of companies. Whereas ${ }^{(38-43)}$ also considered three subcategories of IC: human capital, organizational capital, and social capital:

- Human capital: at the individual level (what corresponds to individual knowledge, both tacit and explicit). It refers to the knowledge and skills of the employees who belong to 
the company. Organizational capital: corresponds to aspects of explicit knowledge that can be documented and stored.

- Social capital: appears because of collaboration and interaction between those who share their ideas.

On the other hand, ${ }^{(44)}$ developed a KM evaluation model, based on the general systems theory, which is typified by its holistic and comprehensive perspective: there is a relationship between the whole (assessment model) and its parts (dimensions, categories, variables, and indicators), and the existence and importance of frontier processes (system-environment relationship) is recognized, such as tacit and explicit knowledge. Likewise, this model is conceived from the perspective of process management, an approach that consists of the systematic identification and management of the processes developed in the organization and in their interactions. The model was validated in the SMEs tourism operators of Caldas' Department of Colombia and results of SMEs in the tourism sector of the Caldas Department of Colombia, resulted in the model observed in Figure 1.

\subsection{The touristic sector of Caldas' department}

Nowadays, it is recognized the economic, social, and political importance of the touristic sector in Colombia, especially for the region of the coffee axis and the Department of Caldas, even tourism could be seen with a high potential for growth and development as in other departments and municipalities of the region has come to constitute a high percentage of local GDP. Tourism implies thinking about the permanent demand of human beings to discover spaces, gastronomy, cultural habits, customs, and other attractions that allow them to feel globally from their locations.

According to ${ }^{(45)}$, Colombia is a country with a population of approximately 45.7 million inhabitants in 2010, and during the same year received approximately 2.15 million foreign visitors, which represents a tourist intensity (foreign tourists / inhabitants) of 0.05 , a value that could be qualified as very low if one considers the extraordinary potential that tourism has in Colombia attending to its natural and cultural attractions.

The important growth that tourism has experienced in Colombia in the last decade is highlighted, in the year 2000, a total of 557,280 foreign travelers visited Colombia, compared to an estimated $1,474,863$ people in 2011 , which means having multiplied by three the number of visitors in a decade. In this case, the Department of Caldas has an area of $7,888 \mathrm{~km}^{2}$ and a projected population for 2016 of 989,942 inhabitants. Its capital is Manizales. According to ${ }^{(9)}$, the tourist sector of Caldas is characterized by:

There are a total of 424 suppliers of tourist services in the department of Caldas, where 67\% of the suppliers are gastronomic establishments and bars, $21 \%$ are accommodation and lodging establishments, $5 \%$ are transport companies, $5 \%$ are tourist guides and the remaining $2 \%$ are travel and tourism agencies.

Next $73 \%$ of tourism service providers are registered with the Chamber of Commerce of Manizales de Caldas and only $22 \%$ have the National Tourism Registry - RNT. These figures, and especially the last one, are an issue that the government should promote, and tourism service providers should understand the importance of having such a register. This serves as a mechanism of identification and, having it, is synonymous with legality, security, and quality in their services. And finally, there is the issue of the bilingualism of the personnel who work in the sector, $84 \%$ of touristic services providers do not handle a second language, which is a worryingly high figure, especially in the context of globalization, free trade agreements and the declaration of the Coffee Cultural Landscape PCC as cultural heritage of humanity by 


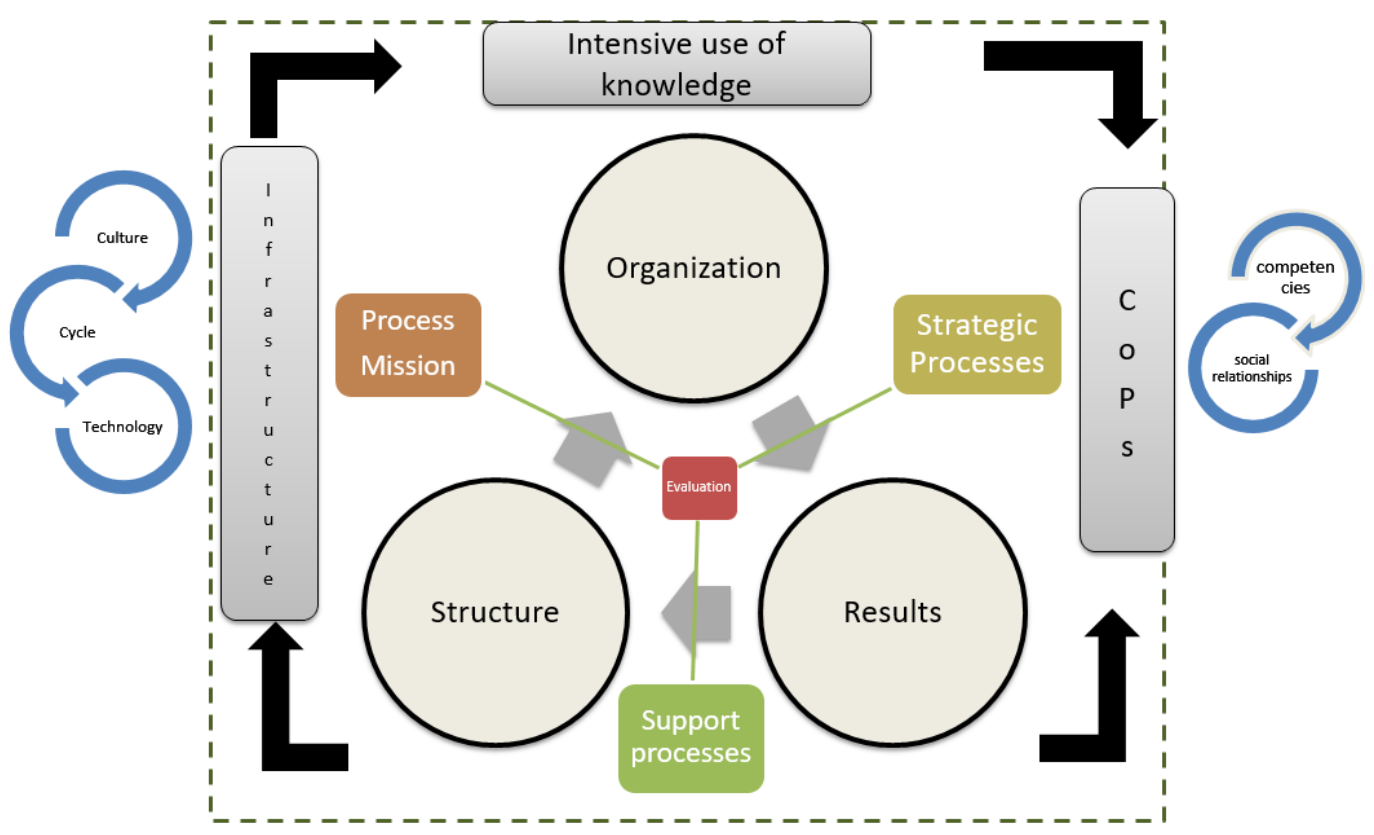

Figure 1. Model of evaluation. Source: own elaboration.

UNESCO. There are certain weaknesses in the technical standards of infrastructure, management, and customer service that touristic services providers must meet in order to integrate quality standards at the national and international levels.

\section{Methodology}

According to the kind of scope, the results are part of qualitative research, as well as a type of confirmatory and correlational study, from the construction of the model and its validation in the SMEs of the touristic sector of Caldas' Department, which is composed of four dimensions of KM and IC. The scale of measurement was Likert, with a range of 1 to 5, where: disagreement or not carried out (1), partially carried out (2), carried out in time intervals (3), carried out regularly (4) and carried out completely (5). In this sense, ${ }^{(44)}$ explains the first three dimensions; in the infrastructure dimension the following categories are considered:
- KM life-cycle: understood as a continuous process that makes it possible for knowledge to be transversal to each and every one of the organizational processes.

- Digital technologies: understood as fundamental tools for $\mathrm{KM}$ that are used pervasively in organizations and therefore qualify as a natural means for the knowledge flow.

- Organizational culture: understood as the set of habits, rituals, regulations, and ways of acting of an organization that serves as a facilitator of the relationship between staff and organizational knowledge and determines that knowledge belongs to the organization and remains under individuals and groups control.

On the other hand, the knowledge-intensive dimension includes the following categories:

- Strategic processes: are those that support the organizational strategy, which involves 
the management of the entity, in terms of decision making that affect the other processes of the organization.

- $\quad$ Core processes: are those that combine and transform resources to obtain the product or provide the service according to the customer's requirements.

- Support processes: are those that provide people and the physical and financial resources required for the remaining processes, and according to the requirements of their internal customers.

Next, in terms of the communities of practice dimension, the categories considered are as follows:

- Personal competencies: refer to the set of knowledge, attitudes, skills, and concerns of people in an organization that makes it competitive, since they cannot be easily replicated.

- Social relations: are those that are generated and built from the values of cooperation and organizational interaction, and that is necessary to share and apply knowledge.

Moreover, this article added the following categories to the evaluation model in relation to IC:

- Structure: understood as the support of SMEs related to the basic characteristics of the employees who work in them.

- Outcomes: are those related to customer and stakeholder orientation.

These categories and variables arise from the existing theoretical review (QA evaluation model) and from the research work that the authors have been developing in relation to the research topic.
The economic sector of this study, in which the model presented was applied and contrasted, corresponds to SMEs in the touristic sector of the Caldas department (Colombia). To obtain the data, it proceeded to review the number of SMEs, which were identified as touristic operators, which allowed to identify a population of 70 companies, of which 61 gave an affirmative response to participation in the study $(n=87.14 \%$ of the population).

\section{Results}

In the validation framework, the existence of a correlation between KM related variables was found, as can be seen in Figure 2. The results in red show a low correlation with values between 0.2 and 0.39 ; the results in yellow show a moderate correlation with values between 0.4 and 0.59 and the results in green show a high correlation with values between 0.6 and 0.8 .

Figure 2 confirms the stability of the evaluation model, and its accordance with the use of the correlation technique to validate a theoretical construct, as described in the studies done by ${ }^{(46-}$ 50). These findings are highlighted in the framework of intellectual capital as a reality applied to the needs of companies, in terms of customer orientation (ORI), customer loyalty (FID), agreements signed with other organizations (CONV) and corporate social responsibility (RES) that the companies evaluated have been doing, as can be seen in Figure 3.

According to the rating scale the variables: customer orientation (ORI), customer loyalty (FID) and agreements signed with other organizations (CONV), have a rating of 4 , that is, made regularly, which could be explained by the advance that has been leading touristic operators in the region and in this measure the increasing use of tourism-related services, which implies a continuous observation of the characteristics and variables of a changing market and its needs. 


\begin{tabular}{|c|c|c|c|c|c|c|c|c|c|c|c|c|c|c|c|c|c|c|c|c|c|c|c|}
\hline & ICI1 & ICG2 & ICR3 & ICO4 & ICA5 5 & ITB6 & ITM7 & ITT8 & ICR9 & ICN10 & ICS11 & UEP12 & UEI13 & \begin{tabular}{|l|l|} 
UM14 \\
\end{tabular} & UF15 & \begin{tabular}{|l|} 
UM16 \\
\end{tabular} & \begin{tabular}{|l|l|} 
UT17 \\
\end{tabular} & \begin{tabular}{|l|} 
UJ18 \\
\end{tabular} & \begin{tabular}{|l|l|} 
US19 \\
\end{tabular} & \begin{tabular}{|l|l|} 
CL20 \\
\end{tabular} & CP21 & CR22 & CW23 \\
\hline ICII & 1,0 & & & & & & & & & & & & & & & & & & & & & & \\
\hline ICG2 & $48^{* \prime}$ & 1,0 & & & & & & & & & & & & & & & & & & & & & \\
\hline ICR3 & $.57^{* \prime}$ & $50^{\circ 1}$ & 1,0 & & & & & & & & & & & & & & & & & & & & \\
\hline ICO4 &, $72^{\prime \prime}$ &, $53^{\circ 1}$ &, $73^{\circ}$ & 1,0 & & & & & & & & & & & & & & & & & & & \\
\hline ICA5 &, $71^{*}$ &, $50^{\circ-1}$ &, $74^{\prime \prime}$ &, $71^{\prime \prime}$ & 1,0 & & & & & & & & & & & & & & & & & & \\
\hline ITB6 &, $65^{* *}$ &, $37^{\circ}$ &, $63^{\circ *}$ &, $74^{* \prime}$ & , $63^{* \prime}$ & 1,0 & & & & & & & & & & & & & & & & & \\
\hline ITM7 &, $62^{* *}$ & $.36^{\circ}$ &, $62^{\circ}$ &, $68^{* \prime}$ &, $61^{* \prime}$ &, $71^{*}$ & 1,0 & & & & & & & & & & & & & & & & \\
\hline ITT8 &, $64^{\prime \prime}$ &, $43^{\prime \prime}$ &, $63^{\circ \prime}$ &, $74^{*}$ &, $63^{*}$ &, $78^{\prime \prime}$ &, $78^{* \prime}$ & 1,0 & & & & & & & & & & & & & & & \\
\hline ICR9 &, $63^{\prime \prime}$ &, $56^{\circ}$ &, $67^{*}$ &, $71^{*}$ &, $66^{*}$ &, $72^{\circ}$ &, $71^{*}$ &, $77^{+1}$ & 1,0 & & & & & & & & & & & & & & \\
\hline ICN10 &, $68^{\circ}$ &, $55^{\circ}$ &, $67^{\circ}$ &, $76^{\circ}$ &, $72^{*}$ &, $71^{*}$ &, $70^{\circ-}$ & ,79. & $81^{* \prime}$ & 1,0 & & & & & & & & & & & & & \\
\hline ICS11 &, $59^{\circ}$ &, $51^{* 1}$ &, $68^{\circ \prime}$ &, $75^{* *}$ &, $63^{*}$ & $65^{\circ}$ &, $59^{\circ *}$ &, $68^{* 1}$ &, $74^{* \prime}$ &, $70^{* 2}$ & 1,0 & & & & & & & & & & & & \\
\hline UEP12 &, $66^{\circ}$ &, $43^{\circ}$ &, $71^{*}$ &, $75^{\circ}$ &, $72^{*}$ &, $62^{\circ}$ &, $64^{* *}$ &, $68^{* *}$ &, $68^{*}$ &, $72^{*}$ &, $78^{* \prime}$ & 1,0 & & & & & & & & & & & \\
\hline UEI13 &, $61^{*}$ &, $44^{\prime \prime}$ &, $78^{\prime \prime}$ & $81^{\prime \prime}$ & , $69^{\circ \prime}$ &, $677^{* *}$ &, $65^{\circ}$ &, $72^{* *}$ &, $71^{*}$ &, $75^{\circ}$ &, $74^{* \prime}$ & $81^{\prime \prime}$ & 1,0 & & & & & & & & & & \\
\hline UM14 &, $63^{\circ \prime}$ &, $41^{\circ}$ &, $79^{\circ *}$ &, $72^{*}$ &, $79^{*}$ &, $66^{\circ 1}$ &, $68^{\circ}$ &, $69^{\circ}$ &, $64^{\prime \prime}$ &, $68^{\circ \prime}$ &, $69^{*}$ &, $74^{\prime \prime}$ &, $77^{* \prime}$ & 1,0 & & & & & & & & & \\
\hline UF15 &, $50^{\circ-}$ & $30^{\circ}$ & $.57^{\circ}$ & ,59" & $.46^{\circ}$ &, $50^{\circ \prime}$ &, $58^{\circ \prime}$ &, $55^{*}$ &, $55^{\circ}$ &, $51^{\prime \prime}$ &, $63^{*+}$ &, $60^{\circ-}$ &, $69^{\prime \prime}$ & $64^{-1}$ & 1,0 & & & & & & & & \\
\hline UM16 &, $46^{\circ}$ &, $51^{\circ 1}$ & $.57^{\circ}$ & , $69^{\circ *}$ &, $45^{*}$ &, $50^{\circ \prime}$ &, $55^{*}$ &, $70^{\circ-1}$ &, $61^{*}$ &, $59^{\circ \prime}$ &, $61^{*}$ &, $53^{\circ}$ &, $62^{\circ \prime}$ &, $51^{\prime \prime}$ &, $60^{\circ 1}$ & 1,0 & & & & & & & \\
\hline UT17 & $.56^{\circ}$ &, $44^{* 1}$ & $.59^{\circ}$ &, $68^{* \prime}$ & $.57^{* *}$ &, $75^{\circ}$ &, $64^{\circ \prime}$ &, $82^{\circ}$ &, $69^{\circ}$ &, $70^{\circ}$ &, $56^{*}$ &, $56^{\circ}$ &, $68^{* \prime}$ &, $60^{\circ-1}$ &, $57^{* 1}$ &, $73^{1 *}$ & 1,0 & & & & & & \\
\hline UJ18 &, $60^{\circ}$ &, $33^{\circ}$ &, $62^{\circ}$ &, $63^{*}$ &, $57^{* *}$ &, $70^{\circ *}$ &, $67^{*}$ &, $76^{\circ}$ &, $72^{*}$ &, $66^{\circ}$ &, $71^{*}$ &, $75^{\circ \prime}$ &, $74^{\prime \prime}$ &, $70^{\circ *}$ &, $72^{*}$ &, $59^{\prime \prime}$ &, $73^{* \prime}$ & 1,0 & & & & & \\
\hline US19 & $.38^{\circ \prime}$ & $.44^{\circ}$ &, $51^{\prime \prime}$ &, 54 & $.46^{\prime \prime}$ &, $43^{\prime \prime}$ &, $43^{*}$ &, $57^{\circ \prime}$ &, $67^{* \prime}$ &, $57^{* \prime}$ &, $66^{\circ}$ &, $53^{\circ *}$ &, $62^{\circ}$ &, $48^{\prime \prime}$ &, $58^{\prime \prime}$ &, $55^{*}$ & , $44^{* *}$ &, $58^{-1}$ & 1,0 & & & & \\
\hline CL20 & $31^{\circ}$ &, $35^{\circ}$ &, $59^{\circ \prime}$ &, $53^{*}$ &, $53^{* \prime}$ &, $43^{\prime \prime}$ & $38^{* *}$ &, $46^{\prime \prime}$ &, $54^{* \prime}$ &, $54^{\circ \prime}$ &, $60^{\circ}$ &, $43^{\circ}$ &, $59^{\circ-}$ &, $55^{*}$ &, $42^{* *}$ &, $48^{\prime \prime}$ &, $48^{\prime \prime}$ & , $44^{\prime \prime}$ &, $56^{\prime \prime}$ & 1,0 & & & \\
\hline CP21 & $40^{\circ-}$ &, $40^{\circ}$ &, $71^{*}$ &, $62^{* *}$ &, $61^{*}$ &, $49^{\circ *}$ &, $52^{*}$ &, $60^{\circ}$ & $.59^{* *}$ &, $65^{\circ \prime}$ &, $60^{\circ *}$ &, $63^{*}$ &, $70^{\circ-}$ &, $72^{* *}$ &, $52^{\circ *}$ &, $55^{\circ}$ &, $52^{\circ}$ &, $59^{*-}$ &, $62^{*}$ & $74^{\prime \prime}$ & 1,0 & & \\
\hline CR22 &, $54^{\prime \prime}$ &, 30 & $.66^{\circ}$ &, $70^{\circ *}$ &, $69^{* \prime}$ &, $60^{\circ \prime}$ &, $60^{\circ}$ &, $65^{\circ *}$ &, $59^{\circ}$ &, $65^{\circ}$ &, $54^{\prime \prime}$ & ,61" &, $76^{\circ}$ &, $76^{\circ}$ &, $51^{\prime \prime}$ &, 54 & $.60^{\circ}$ &, $65^{\circ}$ &, $45^{\circ}$ &, $67^{\prime \prime}$ &, $77^{\circ \prime}$ & 1,0 & \\
\hline CW23 & $.43^{\circ \prime}$ &, $40^{\circ}$ & $.53^{\circ \prime}$ &, $66^{\circ \prime}$ &, $53^{\circ}$ &, $47^{* \prime}$ &, $51^{\circ "}$ &, $64^{* \prime}$ & $.62^{\circ+}$ &, $65^{\circ}$ &, $63^{\prime \prime}$ &, $57^{\circ \prime}$ &, $71^{* *}$ &, $58^{\circ \prime}$ &, $54^{\prime \prime}$ &, $63^{\prime \prime}$ &, $56^{\circ \prime}$ &, $54^{\prime \prime}$ &, $67^{* 1}$ & $64^{* \prime}$ &, $71^{\prime \prime}$ &, $69^{\prime \prime}$ & 1,0 \\
\hline
\end{tabular}

Figure 2. Correlation analysis. Source: own elaboration

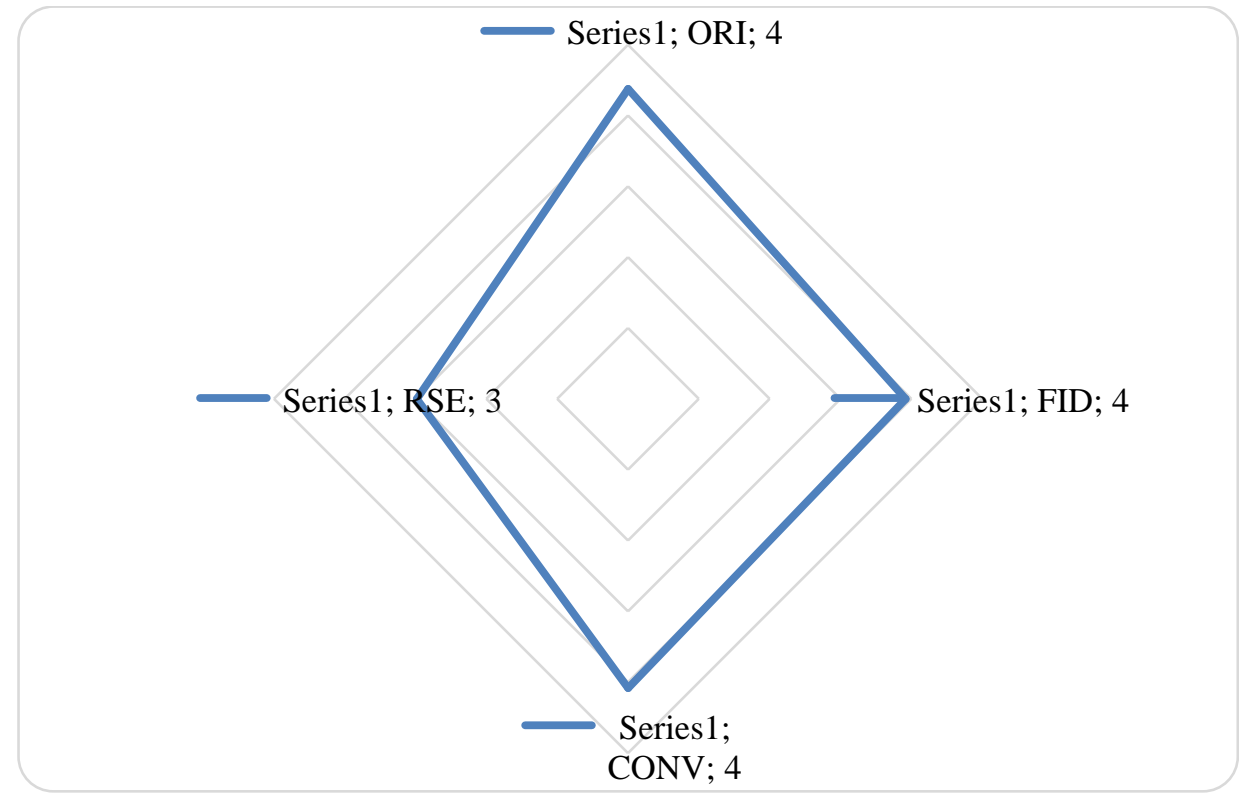

Figure 3. Intellectual capital elements. Source: own elaboration

However, with respect to the variable corporate social responsibility (RES), it is valued at 3, that is, carried out regularly, which shows the recognition of the companies evaluated with respect to the need to consider socially responsible and sustainable tourism with the environment and with the interest groups that are using them; however, it is necessary to make 
permanent progress in this aspect, given the current demands of a market and legal regulations with respect to competitiveness.

On the other hand, the findings show a negative trend related to the use of Information and Communication Technology (ICT) tools (in the correlation Table 1 variables ITB6, ITM7 and ITT8 less than 0.5): website, mobile application(s) applied to the service, access to WiFi zone, access to online information, quick response code $(\mathrm{QR})$, electronic touch screen, call center service, e-tourism recommendation system, orientation and information service, etour map, smart cards, tourist flow monitoring, crowd management, smart education, management of electronic complaints, mobile payment, online booking, forecasting waiting time, weather forecast, real-time traffic transmission, traffic safety protection, virtual tourism experience, augmented reality and blogs of tourist attractions, for tourism in the Department of Caldas, which does not contribute to the generation of value of the tourism proposal of this region.

On the other hand, within the context of the reality of the services provided by the tourism service provider in Caldas and their IC relationship, it is evident the need to make visible their development in terms of customer focus and in this sense, the valuation was high in most of the variables evaluated, which shows the direct relationship between the customer and the IC, in this sense authors such as (51-55) among others, conclude in the same line of the results achieved against the service.

As for the use of various ICT tools in the framework of the IC, according to research results, such as those raised by ${ }^{(56-60)}$ among others, the dynamics of the importance of the use of this type of tools to improve $\mathrm{KM}$ and IC is clear, a fact that goes contrary to the findings of the research, since there is no evidence of the use of these tools to improve $\mathrm{KM}$ and IC, which makes it necessary to design strategies to solve these structural dynamics in this class of companies. In this scenario, it is not possible to precisely conclude the cause or causes of this situation, which makes it necessary to carry out further research on the subject.

It derives from these ICT use and appropriation gaps that data management is incipient, therefore, data are not used to make decisions supported in data analysis and incorporate them into personalized, intelligent, or innovative services. If we articulate KM, IC, and ICT, they will allow to diversify the services offered and to provide complete packages, leveraging the offer and collective services over individual ones. In view of this, it is necessary to continue valuing knowledge management and to formulate strategies that allow knowledge to be incorporated as one of the most important assets (61).

\section{Conclusions}

The basic evaluation model for the research process was approached from a holistic and comprehensive point of view, observing the current KM and IC measurement methods, but considering the perceptions of those who work day by day in the tourism SMEs in the Caldas Department, reflecting a reality and a particular context; also taking into account the nature of the core of a company dedicated to a service that, such as tourism, has become a promising factor for regional economic development. This model was based on a theoretical construct which was evaluated and validated with tools for this purpose, as described in the methodology section.

One of the areas to be addressed is first-level employees (intellectual capital related to collaborators who have direct and first-hand contact with tourists), both to incorporate good practices and lessons learned and to customize 
services and know the customers in depth to provide service experiences, a trend that makes a worldwide difference in tourism.

For the companies of the tourist sector of the Caldas Department it is imperative to maintain levels of competitiveness that can face competition and allow them to remain in the market, in besides considering the need for the country to promote its exports, high value-added services, innovation, local and foreign investment, formal employment and regional convergence as key factors.

From the conceptual point of view, it is expected to contribute to the knowledge base developed in the discipline of KM and IC. From the pragmatic point of view, it is expected to provide solutions to the several problems of the companies of the sector, considering the KM and IC approach.

Colombia plans a future development of the cultural industry, of the creative economy, called orange economy, where tourism and knowledge are central and transversal axes, models and research are required to characterize the sector and propose how to manage native knowledge and collaborators of the tourism sector to enhance and generate new dynamics of work.

IC and KM are key factors in the frameworks of quality assurance and technology, process management, human talent management, and digital technologies, they are being factors of assessment in terms of availability, computer security, reliability, and digital welfare, all these factors combined will enable the tourism sector in the region to qualify and be recognized as a firstclass provider.

\section{Acknowledgements and funding statement}

This work is part of the results of the research project entitled "Intellectual capital for the generation of value through knowledge management in companies in the tourism sector of the Department of Caldas", which was registered and funded by the Research office of the Universidad Nacional de ColombiaManizales and Vice-president of Research of Universidad de Caldas, the code Hermes 36752.

\section{References}

(1) Alonso LF, Fernández-Rodríguez CJ. El imaginario Managerial: el discurso de la fluidez en la sociedad económica. Política y sociedad. 2006;43(2):127-151. Available from: https://revistas.ucm.es/index.php/POSO/ article/view/POSO0606220127A.

(2) Sanabria S, Morales $\mathrm{M}$, Arias $\mathrm{M}$. Acumulación de conocimiento, innovación y competitividad en aglomeraciones empresariales. Facultad de Ciencias económicas. 2010;18(2):1953. https://doi.org/10.18359/rfce.2271.

(3) Romer D, Mathison L, Rojas D. A proposal for knowledge managment in small and medium enterprise: an ispace based in ITC/IS. Revista da Micro e Pequena Empresa. 2009;3(2):120-143. Available from: http://www.cc.faccamp.br/ojs-2.4.82/index.php/RMPE/article/view/64.

(4) Meisel S, Bermeo $\mathrm{H}$, Oviedo L. Generación de valor a través de la gestión estratégica del conocimiento, innovación y la mejor continua. Scientia et Technica. 2006; 32(1): 165-170. Available from: https://revistas.utp.edu.co/index.php/revi staciencia/article/view/6419.

Sandberg M, Klockars K, Wilén K. Green growth or degrowth? Assessing the normative justifications for environmental sustainability and economic growth through critical social 
theory. Journal of Cleaner Production. 2019;206:133-141.

https://doi.org/10.1016/j.jclepro.2018.09. 175 .

(6) Wang MH, Yang TY. Investigating the success of knowledge management: An empirical study of small and mediumsized enterprises. Asia Pacific Management Review. 2016; 21(2): 7991.

https://doi.org/10.1016/j.apmrv.2015.12. 003.

(7) Sheng-Hshiung T, Wei-Rong L, ChangHua Y. Place- and activity-related antecedents of challenge perception in adventure tourism. Journal of Outdoor Recreation and Tourism. 2020; 31:100318.

https://doi.org/10.1016/j.jort.2020.10031 8.

(8) Mendez J. El turismo de naturaleza es la apuesta del departamento. Periódico La Patria [www.lapatria.com]. 2013 [cited 201311 18]. Available from: https://www.lapatria.com/negocios/elturismo-de-naturaleza-es-la-apuesta-deldepartamento-jefe-de-unidad-deturismo-48482

(9) Toro-Galvis JM, Ocampo-López, OL, Ovalle-Castiblanco AM, Serna-López, ML. Impactos del programa Alianzas para la Innovación en empresas del sector TIC de Caldas. Scientia et technica. 2019;24(3), 436-445. https://doi.org/10.22517/23447214.2075 1.

(10) Tsoukas $\mathrm{H}$, Vladimirou E. What is Organizational Knowledge? Journal of Management Studies. 2001; 38(7), 974993. https://doi.org/10.1111/14676486.00268 .
(11) Davenport TH, Prusak L. Working Knowledge: How organizations manage what they know. Cambridge: Harvard University Press; 1998.

(12) Civit RA, Siever A. La gestión integral del conocimiento y del aprendizaje. Economía Industrial. 1999; 326: 63-72.

Alavy M, Leidner D. Review knowledge management and knowledge management systems conceptual foundations and research issues. MIS Quarterly. 2001;25(1):107-136. https://doi.org/10.2307/3250961.

(14) Earl M. Knowledge Management Strategies: Toward a Taxonomy. Journal of Management information Systems. 2001; 18(1):215-233. https://doi.org/10.1080/07421222.2001.1 1045670.

(15) Riesco M. El negocio es el conocimiento. Madrid: Díaz de Santos. 2006.

(16) Barney J. Firm Resources and sustained competitive advantage. Journal de of management. 1991; 17(1): 99-100. https://doi.org/10.1177/01492063910170 0108.

Dosi G, Teece DJ, Winter S. Toward a theory of corporate coherence: Preliminary Remarks. In: Dosi G, Toninelli eds. Technology and Enterprise in a Historical Perspective. Oxford: Clarendon Press of Oxford University Press; 1992.

Arthur J, Huntley C. Ramping up the organizational learning curve: Assessing the impact of deliberate learning on organizational performance under gainsharing. Academy of Management Journal. 2005; 48 (6): 1159-1170. 
https://doi.org/10.5465/amj.2005.195731

15.

(19) Collins C, Smith K. Knowledge exchange and combination: The role of human resource practices in the performance of high-technology firms. Academy of Management Journal. 2006; 49(3): 544-560.

https://doi.org/10.5465/amj.2006.217946 71.

(20) Mesmer-Magnus J, DeChurch L. Information sharing and team performance: A meta-analysis. Journal of Applied Psychology. 2009; 94(2):535-546.

https://doi.org/10.1037/a0013773.

(21) Lin H. Knowledge sharing and firm innovation capability: An empirical study. International Journal of Manpower. 2007; 28(3/4): 315-332. https://doi.org/10.1108/01437720710755 272.

(22) Barroso-Rodríguez G, DelgadoFernández M. Gestión del cambio organizacional a través de proyectos. Ingeniería Industrial. 2007;28(1):42-47. Available from: https://rii.cujae.edu.cu/index.php/revistai nd/article/view/69.

(23) Barragán A. Aproximación a una taxonomía de modelos de gestión del conocimiento. Intangible Capital. 2009; 5(1):65-101.

https://doi.org/10.3926/ic.2009.v5n1.p65 $-101$.

(24) Morin E. Introducción al Pensamiento Complejo. Barcelona: Editorial Gedisa S.A. 1994.

(25) Salazar F. Estrategias para la implementación de Gestión del
Conocimiento para la empresa UNETelefónica de Pereira. [Master's Thesis]. Manizales: Universidad Nacional de Colombia sede Manizales; 2014. Avaible from:

https://repositorio.unal.edu.co/handle/un $\mathrm{al} / 31080$.

(26) Harrison J, Lin Z, Carroll G, Carley K. Simulation modeling in organizational and management research. Academy of Management Review. 2007; 32(4): 12291245.

https://doi.org/10.5465/amr.2007.265864 85.

Buckley PJ. The theory and empirics of the structural reshaping of globalization. Journal of International Business Studies. (2020); 51(9): 1580-1592. https://doi.org/10.1057/s41267-02000355-5.

(28) Wiig K. Integrating Intellectual Capital and Knowledge Management. Long Range Planning. 1997; 30(3): 399-405. https://doi.org/10.1016/S00246301(97)90256-9.

(29) Roos G, Roos J. Measuring your Company's Intellectual Performance. Long Range Planning. 1997; 30(3): 413 426. https://doi.org/10.1016/S00246301(97)90260-0.

(30) Brooking A. The Management of Intellectual Capital. Long Range Planning. 1997; 30(3): $364-365$. https://doi.org/10.1016/S00246301(97)80911-9.

(31) Joia L. The impact of government-togovernment endeavors on the intellectual capital of public organizations. Government Information Quarterly. 2008; 25(2): 256-277. 
https://doi.org/10.1016/j.giq.2007.06.004

Hsu YH, Fang W. Intellectual capital and new product development performance: The mediating role of organizational learning capability. Technological Forecasting \& Social Change. 2009; 76(5): 664-677. https://doi.org/10.1016/j.techfore.2008.0 3.012 .

(33) Rossi C, Cricelli, L, Grimaldi M, Greco, M. The strategic assessment of intellectual capital assets: An application within Terradue Srl. Journal of Business Research. 2016; 69(5): 1598-1603. https://doi.org/10.1016/j.jbusres.2015.10 .024 .

(34) Patthirasinsiri N, Wiboonrat $\mathrm{M}$. Measuring intellectual capital of science park performance for newly established science parks in Thailand. Kasetsart Journal of Social Sciences. 2019; 40(1):82-90. Available from: https://so04.tci-

thaijo.org/index.php/kjss/article/view/23 5377.

(35) Nuryaman. The Influence of Intellectual Capital on The Firm's Value with The Financial Performance as Intervening Variable. Procedia - Social and Behavioral Sciences. 2015; 211: 292 298.

https://doi.org/10.1016/j.sbspro.2015.11. 037.

(36) Mehralian G, Reza H, Akhavan P, Rajabzadeh A. Prioritization of intellectual capital indicators in knowledge-based industries: Evidence from pharmaceutical industry. International Journal of Information Management. 2013; 33(1): 209-216. https://doi.org/10.1016/j.ijinfomgt.2012. 10.002 .

Carmona-Lavado A, Cuevas-Rodríguez G, Cabello-Medina C. Social and organizational capital: Building the context for innovation. Industrial Marketing Management. 2010; 39(4): 681-690.

https://doi.org/10.1016/j.indmarman.200 9.09.003.

(38) Costa R. Assessing Intellectual Capital efficiency and productivity: An application to the Italian yacht manufacturing sector. Expert Systems with Applications. 2012; 39(8): 72557261.

https://doi.org/10.1016/j.eswa.2012.01.0 99.

(39) Fan I, Lee R. Design of a weighted and informed NK model for intellectual capital-based innovation planning. Expert Systems with Applications. 2012; 39(10): 9222-9229.

https://doi.org/10.1016/j.eswa.2012.02.0 83.

(40) Gadau L. The intellectual capital a significant, but insufficiently highlighted source in the financial situations. Procedia - Social and Behavioral Sciences. 2012;62:668-671. https://doi.org/10.1016/j.sbspro.2012.09. 113.

(41) Nedjati A, Izbirak G. Evaluating the Intellectual Capital by ANP Method in a Dairy Company. Procedia - Social and Behavioral Sciences. 2013; 107: 136144.

https://doi.org/10.1016/j.sbspro.2013.12. 840. 
(42) Kalkan A, Bozkurt Ö, Arman M. The impacts of intellectual capital, innovation and organizational strategy on firm performance. Procedia - Social and Behavioral Sciences. 2014; 150: 700707.

https://doi.org/10.1016/j.sbspro.2014.09. 025 .

(43) Chen DN, Liang TP. Knowledge evolution strategies and organizational performance: A strategic analysis. Electronic Commerce Research and Applications. 2011; 10(1): 75-84. https://doi.org/10.1016/j.elerap.2010.10. 004.

(44) Marulanda C, Giraldo J, Serna H. Modelo de evaluación de gestión del conocimiento para las pymes del sector de tecnologías de la información. ADminister. $\quad 2015 ;(26)$ : $\quad$ 17-39. https://doi.org/10.17230/administer.26.2.

Zúñiga-Collazos A, Castillo-Palacio M. Turismo en Colombia: Resultados del sector. Repositorio Universidad Santiago de Cali [www repository.usc.edu.co]. 2012 [cited 202006 27]. Available from:https://repository.usc.edu.co/handle $/ 20.500 .12421 / 2269$

(46) Dickinson DK. Teachers' language practices and academic outcomes of preschool children. Science. 2011; 333(6045): 964-967. https://doi.org/10.1126/science.1204526.

(47) Ghantous N, Das SS, Chameroy F. Governance capabilities and relationship performance in international franchising. Journal of Retailing and Consumer Services. 2018; 40:19-30. https://doi.org/10.1016/j.jretconser.2017. 08.022 .
Smriti N, Das N. The impact of intellectual capital on firm performance: a study of Indian firms listed in COSPI. Journal of Intellectual Capital. 2018; 19(5): 935-964. https://doi.org/10.1108/JIC-11-2017-

0156

(49) Trequattrini R, Lombardi R, Lardo A. The Impact of Entrepreneurial Universities on Regional Growth: a Local Intellectual Capital Perspective. Journal Knowledge Economy. 2018; 9: 199-211. https://doi.org/10.1007/s13132-015-

0334-8.

(50) Mohamad MR, Zin NM. Knowledge management and the competitiveness of small construction firms: Innovation as mediator. Competitiveness Review. 2019; 29(5): 534-550. https://doi.org/10.1108/CR-03-20180027.

(51) Chen CJ, Liu TC, Chu MA, Hsiao YC. Intellectual capital and new product development. Journal of Engineering and Technology Management. 2014; (33): 154-173.

http://dx.doi.org/10.1016/j.jengtecman.2 014.06.003.

Albort-Morant G, Leal-Millán A, Cepeda-Carrión G. The antecedents of green innovation performance: A model of learning and capabilities. Journal of Business Research. 2016; 69(11): 49124917.

https://doi.org/10.1016/j.jbusres.2016.04 .052 .

(53) Waseem B, Loo-See B, Adeel A, Riaz A. Impact of intellectual capital on innovation capability and organizational performance: An empirical investigation. Serbian Journal of Management. 2018; 
13(2):

365-379.

https://doi.org/10.5937/sjm13-16997.

(54)

Jogaratnam G. The effect of market orientation, entrepreneurial orientation and human capital on positional advantage: Evidence from the restaurant industry. International Journal of Hospitality Management. 2017; 60: 104113.

http://dx.doi.org/10.1016/j.ijhm.2016.10. 002.

Li G, Luo Z, Anwar M, Lu Y, Wang X, Liu $X$. Intellectual capital and the efficiency of SMEs in the transition economy China; Do financial resources strengthen the routes? PloS one. 2020; 15(10). $\mathrm{e} 0240774$. https://doi.org/10.1371/journal.pone.023 5462.

(56)

Khalique M, Bontis N, Abdul SJ, Hassan MA. Intellectual capital in small and medium enterprises in Pakistan. Journal of Intellectual Capital. 2015; 16(1): 224238. https://doi.org/10.1108/JIC-012014-0014.

Inkinen $\mathrm{H}$. Review of empirical research on intellectual capital and firm performance. Journal of Intellectual Capital. 2015; 16(3): 518-565. https://doi.org/10.1108/JIC-01-2015-

0002.

(58) Dženopoljac V, Janoševic S, Bontis N. Intellectual capital and financial performance in the Serbian ICT industry. Journal of Intellectual Capital. 2016; 17(2): pp. 373-396. https://doi.org/10.1108/JIC-07-2015-

0068.
De-Carvalho JF, De-Oliveira AC, Quintanilha G. Estudo comparativo sobre a divulgação de intangíveis e capital intelectual em Instituições de Ensino Superior no Brasil e na Áustria. Administração. Ensino e Pesquisa. 2019; 20(2):249-85.

https://doi.org/10.13058/raep.2019.v20n 2.1201 .

(60) Abualoush S, Masa'deh R, Bataineh K, Alrowwad A. The role of knowledge management process and intellectual capital as intermediary variables between knowledge management infrastructure and organization performance. Interdisciplinary Journal of Information, Knowledge and Management. 2018; 13: 279-309. https://doi.org/10.28945/4088.

Ramírez Y. Intellectual capital models in Spanish public sector. Journal of Intellectual Capital. 2010; 11(2): 248264.

https://doi.org/10.1108/14691931011039 705. 